\title{
The comparison of the survival rates of intensive and palliative care units
}

\author{
ilim IRMAK ${ }^{1}$ (ID) \\ Nalan ADIGÜZEL ${ }^{2}$ (ID) \\ Ethem YILDIZ $^{2}$ (ID) \\ Feyza KARGIN ${ }^{2}$ (ID) \\ Özlem YAZICIOĞLU \\ $\operatorname{MOÇiN}^{2}$ (ID) \\ Nezihe ÇiFTASLAN \\ GÖKŞENOĞLU(ID) \\ Döndüye ÖZGÜL ${ }^{2}$ (ID) \\ Zuhal KARAKURT $^{2}($ ID)
}

${ }^{1}$ Department of Chest Diseases, Faculty of Medicine, Hacettepe University, Ankara, Turkey

${ }^{1}$ Hacettepe Üniversitesi Tıp Fakültesi, Göğüs Hastalıkları Anabilim Dalı, Ankara, Türkiye

2 Istanbul Sureyyapasa Chest Diseases and Chest Surgery Training and Research Hospital, Intensive Care Unit, İstanbul, Turkey

${ }^{2}$ Istanbul Süreyyapaşa Göğüs Hastalıkları ve Göğüs Cerrahisi Eğitim ve Araştırma Hastanesi, Yoğun Bakım Ünitesi, İstanbul, Türkiye
Cite this article as: Irmak $i$, Adıgüzel N, Yıldız E, Kargın F, Yazıcıoğlu Moçin Ö, Çiftaslan Göksenoğlu N, et al. The comparison of the survival rates of intensive and palliative care units. Tuberk Toraks 2020;68(3):245-251.

\section{Yazışma Adresi (Address for Correspondence)}

\section{Dr. ilim IRMAK}

Hacettepe Üniversitesi Tıp Fakültesi Hastanesi, Göğüs Hastalıkları Anabilim Dalı ANKARA - TÜRKIYE

e-mail: ilimirmak@hotmail.com

CCopyright 2020 by Tuberculosis and Thorax.

Available on-line at www.tuberktoraks.org.com

\section{ABSTRACT}

The comparison of the survival rates of intensive and palliative care units Introduction: Palliative care is a multidisciplinary therapy formed by physical, social, psychological, cultural and spiritual support of patients and families. The aim of the present study is to compare the survival rates of the intensive care unit (ICU) and palliative care unit (PCU).

Materials and Methods: $A$ retrospective observational cohort study was performed using the database of an intensive care unit. Patients with terminal illness admitted to the intensive care unit or palliative care unit were included in the study. Demographic data, comorbidities, time of admission, discharge and death were recorded. The survival estimation was completed using Kaplan Meier survival analysis.

Results: A total of 112 patients were included in the study. Patients were divided into two groups where 60 patients (53.6\%) were in Group ICU and $52(46.4 \%)$ were in Group PCU. The Kaplan-Meier estimation of survival curves showed that the overall median time was 29 days. This result demonstrated that $50 \%$ of the patients was survived longer than 29 days, in which it was 12 days and 38 days for Group ICU and Group PCU, respectively $(\chi 2=$ $3.475, p=0.062$ ). The cost of either intensive care unit or palliative care unit did not show any difference $(p=0.902)$.

Conclusion: The present study showed that long-term survival rates are similar in intensive care unit and palliative care unit.

Key words: Palliative care; critical care; mortality 


\section{Öz}

\section{Yoğun bakım ve palyatif bakım ünitelerinin sağkalım oranlarının karşılaştırılması}

Giriş: Palyatif bakım, hastaların ve ailelerin fiziksel, sosyal, psikolojik, kültürel ve manevi desteği ile oluşturulan multidisipliner bir tedavi yaklaşımıdır. Bu çalışmanın amacı, yoğun bakım ünitesi (YBÜ) ve palyatif bakım ünitesinin (PBÜ) sağkalım oranlarını karşılaştırmaktır.

Materyal ve Metod: Çalışma retrospektif gözlemsel kohort şeklinde yoğun bakım ünitesinin veri tabanı kullanılarak yapıldı. Yoğun bakım ünitesi veya palyatif bakım ünitesine başvuran terminal hastalığı olan hastalar çalışmaya dahil edildi. Hastaların demografik verileri, komorbiditeleri, yatış, taburculuk ve ölüm tarihleri kaydedildi. Yaşam süresi tahmini ise Kaplan Meier sağkalım analizi kullanılarak yapıldı.

Bulgular: Toplamda 112 hasta çalışmaya dahil edildi. Hastaların 60’ (\%53.6) YBÜ grubu ve 52 hasta (\% 46.4) PBÜ grubu olmak üzere iki gruba ayrıldı. Kaplan-Meier sağkalım tahmin analizi toplam medyan sürenin 29 gün olduğunu göstermiştir. Bu sonuç hastaların \%50'sinin YBÜ grubu ve PBÜ grubu için sırasılla 12 ve 38 gün olduğu, hastaların yarısının 29 günden daha uzun süre hayatta kaldığını göstermiştir $(\chi 2=3.475, p=0.062)$. Yoğun bakım ve palyatif bakım ünitelerinin maliyetleri arasında bir fark saptanmadı ( $p=$ 0.902).

Sonuç: Çalışma uzun dönem sağkalım oranlarının yoğun bakım ve palyatif bakım ünitelerinde benzer olduğunu göstermiştir.

Anahtar kelimeler: Palyatif bakım; yoğun bakım; mortalite

\section{INTRODUCTION}

Death is the inevitable section of life. Terminal illness is defined as having an illness or physical condition that can be expected to end with death in 24 months or less (1). It consists of various diseases from neurological disorders to cancer. In relation, a significant number of terminally ill patients die in hospital, and the majority of these were admitted to ICUs at the end of their last days. Despite life support interventions, it will not improve the condition of the patient but rather will add the agony and burden of a prolonged end of life process. Futile life support has inevitably created economic load on both the patients and families, and also been consuming time and healthcare workforce (2).

Furthermore, palliative care has been started with a hospice and recently become a worldwide treatment strategy consisted of a mixture of academic and non-academic care delivery systems including homecare and hospital-based services (3). The current definition of palliative care has evolved from end of life application to being available for all stages of life-threatening disease and delivered by several modes in various care settings. It has become a multidisciplinary care formed by physical, social, psychological, cultural and spiritual support of patients and families, providing relief of pain and physical symptoms as well (4). Over the past five years, palliative care has been progressively developed in Turkey by the strong efforts of the Ministry of Health from two palliative care units (PCU) to 168 (5). However, the demand for PCU has been increasing by the time and is not be able to fulfill the number of admissions. An estimated 40 million people are in need of palliative care each year, $78 \%$ of those live in low- and middle-income countries. Approximately $14 \%$ of people in the Worldwide who need palliative care currently receive it (6). This situation forced the health care professionals to enroll terminally ill patients to the intensive care units (ICU) rather than PCUs. Consequently, PCUs might serve as an alternative to ICUs those can provide a better end of life environment for the patient and an efficient use of the resources as well. We hypothesized that the survival of the patients in PCUs will be the same as the patients in ICUs.

Therefore, the aim of the present study is to compare the characteristics and survival of terminally ill patients in ICU versus PCU who were admitted to the 3 rd degree respiratory ICU in one year.

\section{MATERIALS and METHODS}

After approval of the local ethics committee of a tertiary teaching hospital (116.2017.010), this retrospective cohort study was initiated and enrolled between October 2014 and October 2016. Patients' data were obtained from the hospital database.

\section{Subjects}

The study included patients admitted in ICU who were diagnosed as terminal illness by a pulmonary specialist and an intensivist. The patients (terminally ill patients in the ICU) were divided into two groups as the ones who were transferred to the PCU from ICU (assigned as Group PCU) or left in ICU (assigned 
as Group ICU). Patients who were not eligible for transfer to PCU associated with the requirement of ICU support were excluded from the study.

\section{Data}

Patient data were collected from the hospital database. The demographics, comorbidities, acute physiology and chronic health evaluation (APACHE) II scores, Charlson's comorbidity index $(\mathrm{CCl})$, number of ICU and hospital admissions, diagnosis (terminal illness), length of stay in ICU or PCU, the cost of the patient whether in ICU or PCU obtained from the hospital database, and time of death gathered from the government electronic mortality declaration system were recorded (7-9).

\section{Definitions}

Terminal illness for the inclusion criteria of this study were classified as follows;

- Advanced cancer with unresponsive to chemotherapy

- End-stage heart failure with ejection fraction less than $20 \%$ or end-stage cardiomyopathy

- End stage chronic obstructive pulmonary disease (COPD) and end-stage interstitial pulmonary fibrosis (IPF) requiring more than 16 hours of noninvasive mechanical ventilation

- Any of the neuromuscular disease requiring more than 16 hours of daily mechanical ventilation, bulbar involvement (amyotrophic lateral sclerosis, motor neuron disease, hypoxic encephalopathy, etc.) or dementia and cerebrovascular accident without maintaining spontaneous respiration and self-feeding.

\section{Statistical Analysis}

The distribution of the variables was analyzed using Shapiro-Wilk test. The data that showed normal and homogeneous distribution in the study were presented as mean and standard deviation, and the data that did not show normal and homogeneous distribution were given as median [interquartile range (IQR) $25 \%-75 \%$ ] values, and also with numbers and percentage values. Age, length of stay in ICU or PCU, $\mathrm{CCl}$, APACHE II score, cost of ICU or PCU of the groups were compared using independent samples $t$ test or Mann-Whitney $U$ test. Categorical data including gender and comorbidities were analyzed by Chisquare test or Fischer exact test. The survival estimation was completed using Kaplan Meier survival analysis. Long-term mortality risk factors were analyzed by Cox-regression analysis. Statistical Package for Social Sciences (SPSS) version 20 program was used for the statistical analysis in the evaluation of the results obtained in the study. The significance level was set at $\mathrm{p}<0.05$.

\section{RESULTS}

A total of 112 patients were included in the study. Patient groups are summarized in a flowchart (Figure 1). Demographic data was presented in Table 1. Patients were divided into two groups where 60

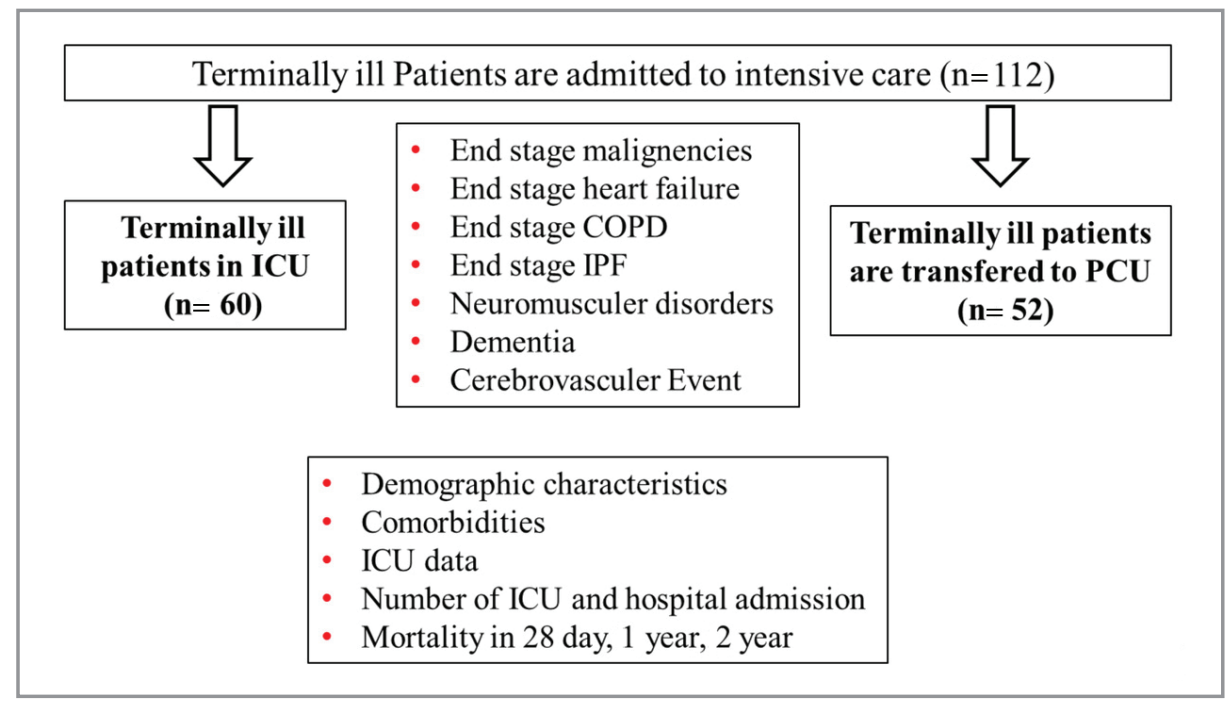

Figure 1. Flow chart of the study. 
The comparison of the survival rates of intensive and palliative care units

Table 1. Demographic data of the subjects

\begin{tabular}{|c|c|c|c|}
\hline & $\begin{array}{c}\text { Group ICU } n=60 \\
\text { Mean } \pm S D\end{array}$ & $\begin{array}{c}\text { Group PCU } n=52 \\
\text { Mean } \pm S D\end{array}$ & $\mathbf{p}$ \\
\hline Age (years) & $67.72 \pm 14.12$ & $71.58 \pm 14.37$ & $0.155^{\mathrm{a}}$ \\
\hline $\mathrm{BMI}\left(\mathrm{kg} / \mathrm{m}^{2}\right)$ & $22.68 \pm 5.72$ & $21.85 \pm 6.43$ & $0.208^{\mathrm{a}}$ \\
\hline $\mathrm{CCl}$ & $6.32 \pm 2.24$ & $6 \pm 1.81$ & $0.418^{\mathrm{a}}$ \\
\hline APACHE II score & $30 \pm 9.09$ & $27.54 \pm 8.16$ & $0.137^{\mathrm{a}}$ \\
\hline Length of ICU or PCU stay (days) & $11.93 \pm 12.32$ & $14.26 \pm 9.88$ & $0.042^{b^{*}}$ \\
\hline \multirow[t]{2}{*}{ Cost (TL) } & $8115.45 \pm 9449.8$ & $7702.61 \pm 8913.91$ & $0.902^{b}$ \\
\hline & n $(\%)$ & n $(\%)$ & \\
\hline \multicolumn{4}{|l|}{ Gender } \\
\hline Male & $45(58.4)$ & $32(41.6)$ & $0.125^{\mathrm{C}}$ \\
\hline \multicolumn{4}{|l|}{ Diagnosis } \\
\hline Malignancy & $32(53.3)$ & $18(34.6)$ & \\
\hline ESND & $15(28.4)$ & $16(30.7)$ & \\
\hline ESPD & $8(13.4)$ & $12(23)$ & \\
\hline ESHF & $3(5)$ & $6(11.5)$ & \\
\hline \multicolumn{4}{|c|}{$\begin{array}{l}\text { BMI: Body mass index, CCI: Charlson comorbidity index, APACHE II: Acute physiology and chronic health evaluation, TL: Turkish lira, ESN } \\
\text { stage neuromuscular disease, ESPD: End stage pulmonary disease, ESHF: End stage heart failure. } \\
\text { aIndependent samples t test. } \\
\text { b Mann-Whitney U test. } \\
{ }^{{ }^{C} C h i-s q u a r e ~ t e s t . ~}\end{array}$} \\
\hline
\end{tabular}

Table 2. Survival of the patients in ICU or PCU

\begin{tabular}{|lccc|} 
& $\begin{array}{c}\text { Group ICU } \mathbf{n}=\mathbf{6 0} \\
\text { Mean } \pm \text { SD }\end{array}$ & $\begin{array}{c}\text { Group PCU } \mathbf{n = 5 2} \\
\text { Mean } \pm \text { SD }\end{array}$ & p \\
\hline Time from admission to death (days) & $144.86 \pm 276.53$ & $170 \pm 302.07$ & $0.001^{*}$ \\
Time from discharge to death (days) & $133.05 \pm 275.06$ & $155.76 \pm 302.7$ & $<0.001^{*}$ \\
\hline Independent samples t test. & & & \\
${ }^{*} \mathrm{p}<0.05$. & & & \\
\hline
\end{tabular}

patients (53.6\%) were in Group ICU and 52 (46.4\%) were in Group PCU. The diagnosis of the patients while admission to either the ICU or PCU were in the following order: malignancy $(n=50,44.6 \%)$, end stage neuromuscular disease $(n=33,29.5 \%)$, end stage pulmonary disease $(n=20,17.9 \%)$, and end stage heart failure $(\mathrm{n}=9,8 \%)$. The mean length of stay in PCU was significantly higher compared to ICU and the cost of stay did not show any significance between the two groups $(p=0.042$ and $p=0.902$, respectively; Table 1 ). The mean survival day in Group PCU was significantly longer than in Group ICU ( $p=0.001$; Table 2). The Kaplan-Meier estimation of survival curves showed that the overall median time was 29 days (Figure 2). This result demonstrated that $50 \%$ of the patients was survived longer than 29 days, in which it was 12 days and 38 days for Group
ICU and Group PCU, respectively $(\chi 2=3.475, \mathrm{p}=$ 0.062 ). Twenty-eight day, one-year and two years mortality were presented in Table 3. A multivariate regression analysis in which $\mathrm{CCl}$, APACHE II score, presence of long-term oxygen therapy (LTOT), longterm mechanical ventilation (LTMV), non-invasive mechanic ventilation (NIMV) and invasive mechanical ventilation (IMV) were assigned as independent possible predictors on two years mortality revealed that $\mathrm{CCl}$ was the significant predictor for mortality in Group ICU, where CCI, APACHE II score, LTMV in Group PCU (Table 4).

\section{DISCUSSION}

The present study showed that two-year mortality rate did not differ between ICU and PCU in spite of the patients admitted to the PCU was survived longer 


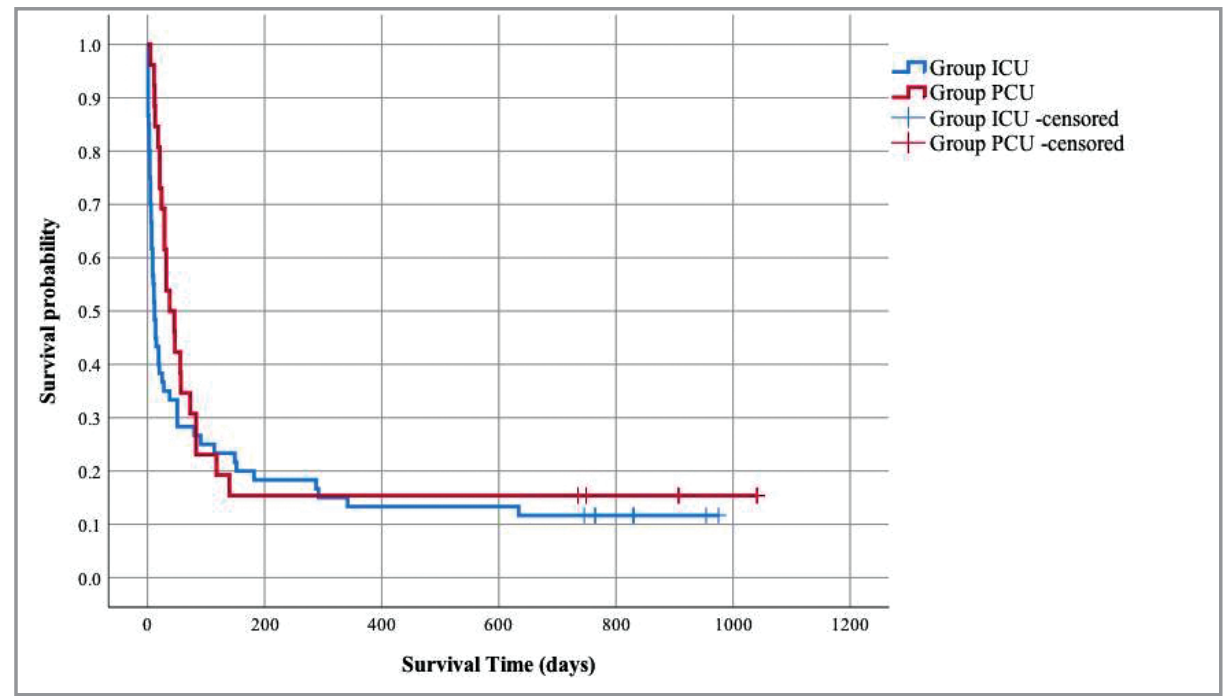

Figure 2. Kaplan-Meier estimation of survival curves.

Table 3. The comparison of the survival of the patients

\begin{tabular}{|lccc|} 
& $\begin{array}{c}\text { Group ICU } \\
(\mathbf{n} / \%)\end{array}$ & $\begin{array}{c}\text { Group PCU } \\
(\mathbf{n} / \%)\end{array}$ & $\mathbf{p}$ \\
\hline 28 days mortality & $39(65)$ & $16(30.8)$ & $<0.001^{*}$ \\
1-year mortality & $52(86.7)$ & $44(84.6)$ & 0.757 \\
2 years mortality & $53(88.3)$ & $44(84.6)$ & 0.564 \\
\hline Chi-square test. & & & \\
* $^{p}<0.05$. & & \\
\hline
\end{tabular}

Table 4. The regression analysis of the groups

\begin{tabular}{|c|c|c|c|c|c|c|}
\hline & \multicolumn{3}{|c|}{ Group ICU } & \multicolumn{3}{|c|}{ Group PCU } \\
\hline & $\beta$ eta & $\mathbf{p}$ & $\mathrm{Cl}$ & ßeta & $\mathbf{p}$ & $\mathrm{Cl}$ \\
\hline $\mathrm{CCl}$ & 0.432 & 0.001 & $-0.122-0.704$ & 0.402 & 0.003 & $0.029-0.133$ \\
\hline APACHE II & 0.078 & 0.574 & $-0.007-0.013$ & 0.395 & 0.009 & $0.005-0.031$ \\
\hline LTOT & 0.089 & 0.557 & $-0.138-0.252$ & 0.024 & 0.864 & $-0.186-0.221$ \\
\hline LTMV & -0.170 & 0.252 & $-0.363-0.097$ & 0.317 & 0.039 & $0.017-0.617$ \\
\hline NIMV & 0.179 & 0.185 & $-0.058-0.295$ & 0.070 & 0.599 & $-0.145-0.249$ \\
\hline IMV & 0.129 & 0.315 & $-0.094-0.285$ & -0.274 & 0.059 & $-0.454-0.009$ \\
\hline
\end{tabular}

than ICU where overall survival was approximately one month. In addition, 28 days mortality rate was higher in patients admitted to ICU than in PCU. The $\mathrm{CCl}$ was the significant predictor for mortality in ICU, where age, APACHE II score, NMD, LTMV, DM, and $\mathrm{HT}$ in PCU.
A comprehensive study by Yun et al. (10) showed that admission to the either ICU or PCU do not change the survival of the patients. They also suggested that ICU may shorten the survival of patients with terminal illness. Although some health care professionals avoid to use of aggressive medical therapy for symptoms in patients with terminal illness suggesting it may cause 
death sooner than expected, several studies demonstrated the positive effects of such therapy on survival (10-13). Palliative care with psychological and social support provides prolonged survival with a better quality of life. It is reported that initiating palliative care in the early period leads improved survival of the patients (14). In this context, the present study revealed that neither palliative care nor ICU shorten the survival of terminally ill patients and have an influence on long term mortality that is in agreement with previous studies mentioned above. However, the higher rate of short-term (28-day) mortality in Group ICU suggested that patients with severe symptoms in PCU had to be transferred to the ICU before death which could cause an increase in the mortality rate of ICU.

Comorbidities such as malignancies, neurological diseases, obesity, septic shock, and renal failure are known to affect the outcomes of the patients in ICU, particularly increasing the mortality rates. Moreover, a comprehensive study by Garcia-Aymerich et al. (15) demonstrated that patients hospitalized by pulmonary disease had an increased mortality which has been reported similarly in various studies $(16,17)$. It was shown that patients admitted to the ICU with pulmonary disease those performed IMV has a higher mortality rate $(18,19)$. Another more common chronic disease, $\mathrm{HT}$, is a significant cardiovascular risk factor and the cause of morbidity and mortality (20). Comorbidities including age and DM are investigated in detail with several studies, and hypoglycemia $(\overline{<}$ $2.2 \mathrm{mmol} / \mathrm{L}$ ) rather than hyperglycemia and age are more likely be associated with increased mortality in ICU (21-23). In relation, scoring systems are very useful in ICU while admission, and Charlson comorbidity index and APACHE II score are both studied extensively for the prediction of mortality $(24,25)$. Interestingly, it is shown that $\mathrm{CCl}$ was the only significant predictor of mortality in ICU, where age, APACHE II score, NMD, LTMV, DM, and HT in PCU, while expecting several predictors for ICU in the present study. However, all of these predictors have low correlation coefficients suggesting a larger sample size is required to conclude an important outcome.

Nevertheless, the present study showed similar results at cost of either ICU or PCU. Studies indicated that palliative care units lower the cost of the health care, even though only $10 \%$ of the patients receive adequate palliative care. Authors also mentioned that palliative care reduces the length of stay which is associated with one-half of the difference (26). In the present study, it can be speculated that the similar cost could be comprised by the longer length of stay in PCU compared to ICU, hence early discharge of the patients from PCU might reduce the cost.

This study has some limitations. First, the study population is very limited due to its retrospective and single centered design. Second, the psychological and social support level could be evaluated for both the ICU and PCU in which might show detailed outcomes for the effectiveness of PCU.

\section{CONCLUSION}

The present study revealed that PCU and ICU has similar long-term survival rates However, further studies with larger sample size are required to elucidate this result.

Ethical Committee Approval: The ethical approval for this study was obtained from the Ethics Committee of Istanbul Surayyapasa Chest Diseases and Chest Surgery Training and Research Hospital. (Decision no: 116.2017.010 Date: 24.05.2017)

\section{CONFLICT of INTEREST}

There is no conflict of interest related to this study.

\section{AUTHORSHIP CONTRIBUTIONS}

\section{Concept/Design: II, NA}

Analysis/Interpretation: II, ZK, FK, ÖYM, NÇG, EY

Data Acquisition: II, FK, ÖYM, NÇG, EY, DÖ

Writting: II, ZK, NA

Critical Revision: ZK, NA

Final Approval: ZK, NA

\section{REFERENCES}

1. Hui D, Nooruddin Z, Didwaniya N, Dev R, De La Cruz M, $\mathrm{Kim} S \mathrm{H}$, et al. Concepts and definitions for "actively dying", "end of life", "terminally ill", "terminal care", and "transition of care": a systematic review. J Pain Symptom Manage 2014; 47: 77-89.

2. Myatra SN, Salins N, lyer S, Macaden SC, Divatia N, Muckaden M, et al. End-of-life care policy: an integrated care plan for the dying: a joint position statement of the Indian society of critical care medicine (ISCCM) and the Indian association of palliative care (IAPC). Indian I Crit Care Med 2014; 18: 615-35.

3. Jaiswal $R$, Alici Y, Breitbart W. A comprehensive review of palliative care in patients with cancer. Int Rev Psychiatry 2014; 26: 87-101.

4. Yates P. Symptom management and palliative care for patients with cancer. Nurs Clin North Am 2017; 52: 179-91. 
5. Hacıkamiloglu E, Utku ES, Cukurova Z, Keskinkilic B, Topcu I, Gultekin M, et al. Community palliative care in Turkey: a collaborative promoter to a new concept in the Middle East. J Public Health Manag Pract 2016; 22: 81-8.

6. Al-Mahrezi A, Al-Mandhari Z. Palliative care: time for action. Oman Med I 2016; 31: 161-3.

7. Rué $M$, Artigas A, Alvarez $M$, Quintana S, Valero C. Performance of the mortality probability models in assessing severity of illness during the first week in the intensive care unit. Crit Care Med 2000; 28: 2819-24.

8. Le Gall JR, Lemeshow S, Saulnier F. A new simplified acute physiology score (SAPS II) based on a European/North American multicenter study. JAMA 1993; 270: 2957-63.

9. Charlson ME, Pompei P, Ales KL, MacKenzie CR. A new method of classifying prognostic comorbidity in longitudinal studies: development and validation. J Chronic Dis 1987; 40: 373-83.

10. Yun YH, Kim SH, Lee KM, Park SM, Lee CG, Choi YS, et al. Patient-reported assessment of quality care at end of life: development and validation of quality care questionnaireend of life (QCQ-EOL). Eur J Cancer 2006; 42: 2310-7.

11. Connor SR, Pyenson B, Fitch K, Spence C, Iwasaki K. Comparing hospice and nonhospice patient survival among patients who die within a three-year window. I Pain Symptom Manage 2007; 33: 238-46.

12. Gagnon B, Mayo NE, Hanley J, MacDonald N. Pattern of care at the end of life: does age make a difference in what happens to women with breast cancer? I Clin Oncol 2004; 22: 3458-65.

13. Zimmermann C, Riechelmann R, Krzyzanowska M, Rodin $G$, Tannock I. Effectiveness of specialized palliative care: a systematic review. JAMA 2008; 299: 1698-709.

14. Temel JS, Greer JA, Muzikansky A, Gallagher ER, Admane $S$, Jackson VA, et al. Early palliative care for patients with metastatic non-small-cell lung cancer. N Engl J Med 2010; 363: 733-42.

15. Garcia-Aymerich J, Serra Pons I, Mannino DM, Maas AK, Miller DP, Davis KJ. Lung function impairment, COPD hospitalisations and subsequent mortality. Thorax 2011; 66: 585-90.

16. Connors AF Jr, Dawson NV, Thomas C, Harrell FE Jr, Desbiens N, Fulkerson WJ, et al. Outcomes following acute exacerbation of severe chronic obstructive lung disease. The support investigators (study to understand prognoses and preferences for outcomes and risks of treatments). Am J Respir Crit Care Med 1996; 154: 95967.
17. Eriksen N, Hansen EF, Munch EP, Rasmussen FV, Vestbo J. Chronic obstructive pulmonary disease. Admission, course and prognosis. Ugeskr Laeger 2003; 165: 3499-502.

18. Ai-Ping C, Lee KH, Lim TK. In-hospital and 5-year mortality of patients treated in the ICU for acute exacerbation of COPD: a retrospective study. Chest 2005; 128: 518-24.

19. Raurich JM, Pérez J, Ibáñez J, Roig S, Batle S. In-hospital and 2-year survival of patients treated with mechanical ventilation for acute exacerbation of COPD. Arch Bronconeumol 2004; 40: 295-300.

20. Danaei G, Ding EL, Mozaffarian D, Taylor B, Rehm J, Murray Cl, et al. The preventable causes of death in the United States: comparative risk assessment of dietary, lifestyle, and metabolic risk factors. PLoS Med 2009; 6: e1000058.

21. Rady MY, Johnson DJ, Patel BM, Larson JS, Helmers RA. Influence of individual characteristics on outcome of glycemic control in intensive care unit patients with or without diabetes mellitus. Mayo Clin Proc 2005; 80: 1558-67.

22. Graham BB, Keniston A, Gajic O, Trillo Alvarez CA, Medvedev S, Douglas IS. Diabetes mellitus does not adversely affect outcomes from a critical illness. Crit Care Med 2010; 38: 16-24.

23. Moreno RP, Metnitz PG, Almeida E, Jordan B, Bauer P, Campos RA, et al. SAPS 3--From evaluation of the patient to evaluation of the intensive care unit. Part 2: development of a prognostic model for hospital mortality at ICU admission. Intensive Care Med 2005; 31: 1345-55.

24. Huang YQ, Gou R, Diao YS, Yin QH, Fan WX, Liang YP, et al. Charlson comorbidity index helps predict the risk of mortality for patients with type 2 diabetic nephropathy. Zhejiang Univ Sci B 2014; 15: 58-66.

25. Hosseini M, Ramazani J. Evaluation of acute physiology and chronic health evaluation II and sequential organ failure assessment scoring systems for prognostication of outcomes among Intensive care unit's patients. Saudi I Anaesth 2016; 10: 168-73.

26. Smith TJ, Cassel JB. Cost and non-clinical outcomes of palliative care. J Pain Symptom Manage 2009; 38: 32-44. 